\title{
Brazil, 1981-2013: the effects of economic growth and income inequality on poverty
}

\author{
Francisco José Silva Tabosa, Pablo Urano de Carvalho \\ Castelar and Guilherme Irffi
}

\begin{abstract}
This study analyses the impact of economic growth and income inequality on poverty in Brazil in the years from 1981 to 2013. A dynamic panel model was used, estimated by the twostep generalized method-of-moments system developed by Blundell-Bond (1998), in order to analyse three scenarios: the first corresponds to the entire period covered by this study (i.e. 1981-2013); the second encompasses the years from 1981 to 1994 (the period leading up to the Real Plan); and the third is the period from 1995 to 2013 (the years following the implementation of the Real Plan). The results indicate that economic growth policies that promote an increase in income in conjunction with a reduction in income disparities are more effective in combating poverty in Brazil than those that focus only on raising mean income levels. The findings also point to the existence of a pro-poor form of growth in the period following the Real Plan.
\end{abstract}

\section{Keywords}

Economic growth, income distribution, poverty, measurement, econometric models, poverty mitigation, economic history, Brazil

\section{JEL classification}

015, C32, C22

\section{Authors}

Francisco José Silva Tabosa is a professor with the Department of Agrarian Economics of the Universidade Federal do Ceará, Brazil. franzetabosa@ufc.br

Pablo Urano de Carvalho Castelar is a professor on the Finance Course in the School of Economics, Administration, Accounting and Actuarial Statistics of the Federal University of Ceara, Brazil. pcastelar@ufc.br

Guilherme Irffi is a professor with the Department of Applied Economics of the School of Economics, Administration, Accounting and Actuarial Statistics of the Federal University of Ceara, Brazil. guidirffi@gmail.com 


\section{Introduction}

Poverty reduction is closely linked to income inequality and mean income levels in a given country or region (Bourguignon, 2002). It is therefore important to determine what type of policy will be the most effective in reversing poverty as rapidly as possible. The question, then, is: Should poverty-reduction policies focus on raising mean income levels or on decreasing income inequality?

In an effort to answer that question, a number of studies have been conducted in recent years on the effects of changes in income levels and in inequality on poverty rates, since economic growth alone has been shown to be ineffective in combating poverty in various countries (and regions) (Ravallion, 1997; Rocha, 2006).

Given that changes in poverty rates may be attributable to a redistribution of income or to economic growth (or both), it is important to gauge the effect that changes in each of these variables have on poverty levels (Ravallion, 1997). Based on the results of this study, an effort is made to identify the most influential factors in terms of poverty reduction.

Ravallion and Chen (1997), for example, estimated the income elasticity of poverty (measured on the basis of the number of persons with incomes of less than US\$ 1 per day) in a sample of developing countries and obtained a value of -3 . This means that, for each $1 \%$ increase in the mean income level, the percentage of persons with incomes below the poverty line shrinks by $3 \%$.

However, there is as yet no consensus about the nature of the interrelationships between poverty, growth and income inequality. According to Barreto (2005), much of the empirical evidence appears to indicate that low-income countries in which there is a low level of inequality will respond better to economic growth policies, whereas those policies will be less effective in higher-income economies with greater levels of inequality; in the latter, policies aimed at reducing inequality will be more effective.

A series of studies on the situation in Brazil ${ }^{1}$ show that poverty levels are more sensitive to policies designed to reduce income concentration than they are to policies aimed at boosting mean income levels. Determining how each of these factors affects the others will therefore make a highly significant contribution to the debate about what types of public policies are the most effective in reducing poverty and inequality.

The study done by Barros and others (2007) confirms that the poverty rate in Brazil is higher than it is in most countries with similar per capita income levels and demonstrates that income inequality is responsible for the fact that economic growth is relatively ineffective in reducing poverty. In other words, the poverty-reducing effect of economic growth is weaker in Brazil than it is in other countries with similar income levels.

According to Rodrik (2000), most of the policies adopted for this purpose focus on spurring economic growth, as an increase in an economy's mean income level and/or a reduction in income inequality, or a combination of the two, can lower poverty rates. It is therefore essential to gauge how much weight should be given to each of these strategies, both at the regional and state levels.

This study uses panel data models to analyse the effects of economic growth and income inequality on poverty rates in Brazil in the period from 1981 to 2013. The persistence of poverty dynamics in Brazil can be examined and estimated by drawing on pooled data and applying ordinary least squares (OLS) based on the within-group method and the generalized method of moments (system GMM), a dynamic panel model estimated using the two-step generalized method of moments or two-step GMM developed by Blundell-Bond (1998).

1 See, for example, Hoffmann (2005), De Lima, Barreto and Marinho (2003) and Menezes and Pinto (2005). 
The main contribution made by this study consists of estimations of model parameters for the subperiods 1981-1994 and 1995-2013 for use in analysing the situation in the periods leading up to and following the Real Plan. These findings can then be used to compare inequality and income elasticities of poverty and extreme poverty in different periods of the economic history of Brazil.

In order to achieve these objectives, this study is divided into five sections, one of which is this Introduction. In the second section, a brief overview is presented of the literature on the impact that economic growth, on the one hand, and income inequality, on the other, have on poverty. This is followed by a description of the database, models and econometric methodology that have been used. An analysis and discussion of the results of the model estimations are presented in the fourth section. The fifth and last section offers concluding remarks.

\section{Literature review: the poverty, economic growth and inequality triangle}

According to Bourguignon (2002), a triangular relationship exists between poverty, economic growth and income inequality whereby their interaction provides the necessary conditions for determining how great an impact an increase in mean incomes or a reduction in inequality will have in terms of poverty reduction. For this study, it seemed fitting to present the empirical evidence gathered in three sections.

The first is devoted to studies on the relationship between poverty and economic growth. The second focuses on an analysis of the relationship between poverty and inequality. The third covers the literature on the relationship between economic growth and income inequality.

\section{Poverty and economic growth}

In the international and national empirical literature on the relationship between economic growth and poverty, two different measurements are used to gauge economic growth: gross domestic product (GDP) and mean income. These studies' findings corroborate each other to the extent that they all indicate that, as noted by Araújo, Tabosa and Khan (2012), there are two fundamental factors at work: the average growth rate and the initial level of income inequality.

The relationship between economic growth and poverty reduction can be measured by estimating the corresponding income elasticity or growth elasticity. If it is high, then public policies designed to combat poverty based on economic growth will be more effective since, in this type of situation, boosting income will have a proportionally greater effect in terms of poverty reduction. On the other hand, if the coefficient of elasticity is low, the most appropriate poverty reduction strategies will be those that combine economic growth with some type of income redistribution (Marinho and Araújo, 2010).

Ravallion and Chen (1997) have estimated income-poverty and income-inequality elasticities on the basis of data from 45 countries. Their results indicate that, if the income level were to rise by $1 \%$ in countries with low levels of inequality, the poverty rate would fall by $4.3 \%$, whereas, in countries with high levels of inequality, the same increase in mean income would lead to a $0.6 \%$ drop in the poverty rate. They thus conclude that, in this latter case, growth has no more than a weak impact on poverty levels. However, if the extent of inequality declines as a result of economic growth, then a greater reduction in poverty will be achieved. 
Chen and Wang (2001) studied the relationships between poverty, income and inequality in China in the 1990s and reached the conclusion that economic growth helped to lower poverty levels but that income concentration helped to raise them.

More recently, Figueiredo and Laurini (2015) undertook an analysis of the elasticity of poverty on an international scale. They seek to apply a non-parametric method to a country panel using the World Bank's PovcalNet database, which includes 139 observations for 93 developing countries. The authors' chief concern was to correct for any problems of endogeneity that might arise as a result of a series of factors, such as simultaneity, financial forces that have the same kind of effect on the components being analysed or the hypothetical situation that is usually assumed to exist in terms of the functional relationships between growth, poverty and inequality (a hypothesis according to which the relationship is linear, whereas there are some indications in the literature that this is not the case).

These authors contend that another contribution made by their work is a determination of the direct and indirect effects of growth on poverty and on inequality based on the non-parametric methodology that they have employed. Their findings indicate that the methodology that is generally used in empirical studies on growth, poverty and inequality usually overestimates the effects of growth on poverty. This implies that economic crises or economic booms have less of an influence on poverty than they are generally assumed to have.

At the national level, using data for 26 Brazilian states covering the period from 1985 to 1999 and a methodological procedure that makes it possible to disaggregate the variation in poverty levels deriving from changes in mean income levels and modifications in income concentration (measured by the Gini coefficient), Marinho and Soares (2003) find proof of the effectiveness of growth as a tool for poverty reduction, especially in the northern states of Brazil. This supports the focus on raising incomes which has been the preferred strategy for fighting poverty in Brazil.

In another work on this topic for Brazil, Hoffmann (2005) uses the database for the 1999 National Household Survey (PNAD) and finds that a 1\% increase in per capita household income in Brazil leads to a $0.84 \%$ reduction in poverty and that the absolute value of the elasticity of poverty rises in step with income and decreases in step with increases in inequality.

Manso, Barreto and Tebaldi (2006) used the PNAD data for 1995-2004 as a source of evidence on the relationships between rising income levels, reductions in poverty levels and the wealth distribution profile. They find that the growth of mean income and income distribution are sufficient to account for a large part of the variations in poverty rates observed at the state level in Brazil. The results of these studies thus demonstrate that growth-oriented tools for combating poverty are more effective when they are combined with income redistribution (Barreto, 2005).

Another point made in a number of studies on the relationship between poverty and economic growth is the importance of determining whether growth is pro-poor or not. Ravallion (2004) distinguishes between two types of pro-poor growth: (i) growth that entails a greater reduction in poverty than would be seen if everyone's incomes had risen by the same proportion (Kakwani and Pernia, 2000), and (ii) growth that reduces poverty, regardless of the proportions involved (Ravallion and Chen, 2003).

In the first case, an analysis can be conducted on the basis of the income elasticity of poverty; if that elasticity is greater than 1 (in absolute terms), then the reduction in poverty will outpace the growth of income (Kakwani and Pernia, 2000). In the second case, regardless of the value obtained for the income elasticity of poverty, if the increase in income translates into a reduction in poverty, then growth is pro-poor (Ravallion, 2004).

The study carried out by França (2010) on pro-poor growth and its regional effects in Brazil is a specific example of this type of analysis and has an objective that is quite similar to the aim of this paper. The results that he obtained using the methodology developed by Kakwani, Khandker 
and Son (2004) to analyse data on the various regions of Brazil for the period 1995-2005 indicate that anti-poverty policies have had a greater impact in the southern and south-eastern parts of the country. The author then calculated the income elasticity and the inequality elasticity of poverty and found that, since the latter was greater than the former, the reduction in inequality as measured by the Gini coefficient was more sensitive to reductions in the level of inequality than to increases in mean income. He then used the methodology developed by Kraay (2004) to determine how much influence is exerted by each component of pro-poor growth and found that increases in income have been relatively more influential than changes in inequality as a source of pro-poor growth in the northeastern region of the country.

Kakwani, Neri and Son (2010) used PNAD data for 1995-2004 and a poverty line that takes into account the cost of living in the various regions of the country ${ }^{2}$ to analyse trends in social indicators based on mean per capita income levels. Their findings indicated that growth in Brazil in the post-Real Plan period was indeed pro-poor.

Netto Júnior and Figueiredo (2014) used a non-parametric approach to analyse pro-poor growth in Brazil and in its main geographic regions and states in the periods 1987-1993, 1993-1999 and 1999-2007. Their results suggest that all parts of the country experienced pro-poor growth in 1987-2007.

\section{Poverty and inequality}

Income inequality is an important aspect of the poverty debate. Poverty is a worldwide problem, and in some countries it persists despite the presence of growing stocks of material wealth. The scope and severity of this problem are demonstrated by the number of persons who are living in poverty in all of the world's countries.

An intrinsic link exists between inequality and poverty. According to Bourguignon (2002) and Ravallion (1997), a decrease in income inequality is an important poverty-reduction tool, whereas economic growth may not be so crucial. They thus conclude that reductions in inequality can play a critical role in ensuring that growth will actually lead to a decline in poverty levels.

Banerjee and Duflo (2003) draw attention to the fact that the relationship between economic growth and inequality is not linear since inequality has both direct and indirect effects on poverty. Figueiredo and Laurini (2015) sought to measure those effects using a panel of 93 countries. These authors confirm the existence of a non-linear association between growth and inequality. They argue that not enough attention is devoted to that relationship in most studies on the subject and that it has a positive link to poverty.

Along these same lines, it has been shown that poverty can be rapidly reduced when a country whose economy is growing has a less unequal distribution of income (Barreto, 2005). Accordingly, in addition to attaining their specific goal, public policies aimed at reducing inequality can also indirectly achieve other economic policy objectives, such as more rapid growth and reductions in poverty. Since poverty is more sensitive to inequality than it is to growth (Marinho and Soares, 2003), anti-poverty policies should focus on methods for diminishing income concentration.

According to Rocha (2006), the poverty rate in Brazil was cut by around two percentage points in 2001-2004 thanks to a number of factors (e.g. changes in the distribution of labour income and increases in social benefits) whose effects varied across regions. This author believes that the persistence of poverty in Brazil is largely attributable to the existing level of inequality. Rocha contends that poverty can be cut both by boosting income and by improving income distribution and that the

2 For further details, see Kakwani, Neri and Son (2010) and Ferreira, Lanjouw and Neri (2003). 
emphasis should be placed on reducing income inequality, because raising income levels without reducing inequality simply defers the challenge of putting an end to poverty to some point of time in the future.

A very high initial level of inequality may dampen the poverty-reduction effects of economic growth, although, based on a review of studies on growth and inequality, Ferreira (1999) concludes that no consensus yet exists as to whether or not growth is influenced by the initial level of income inequality.

In the past few decades, poverty has either declined very little or actually risen in a considerable number of countries. For Fosu (2010), this disappointing outcome is partially attributable to the combination of a concentration of growth and rising income inequality in many Latin American countries.

\section{Growth and inequality}

The literature includes analyses of the relationship between economic growth and inequality that take the causalities existing between these variables into consideration. A wide range of related issues have become subjects of debate, including the causes of inequality, the mechanisms by which inequality is perpetuated over time and the relationship between inequality and the economic development process. Diniz (2005) posits the existence of dual causality between these two variables.

Kuznets' (1955) inverted- $U$ hypothesis serves as the starting point for this line of reasoning, according to which, at first, inequality will increase as economic development takes place, which occurs when an economy makes the transition from a rural model to industrialization (transferring labour from the least productive sector to the most productive one). Later on, inequality will decline once the majority of the workforce is employed in the most productive sector. According to this thesis, development policy could focus entirely on promoting economic growth, since such growth would ultimately lead to a decrease in inequality. In a comparative study of 98 countries, Barro (2000) shows that the Kuznets curve exhibits a certain degree of empirical regularity over time, but that it does relatively little to explain the variation in inequality across countries.

Some authors believe that inequality may be prejudicial to economic growth. As summarized by Castelar (2007), empirical studies, especially those conducted since 1996, show that high initial levels of inequality curb subsequent economic growth. Most of the literature on the subject indicates that a one standard deviation decrease in inequality boosts the annual per capita GDP growth rate by between 0.5 and 0.8 percentage points. However, when using panel data, the relationship between income inequality and economic growth appears to be weaker, which suggests that the empirical regularity seen in the Kuznets curve is robust for cross-sectional data but disappears when fixed country effects are introduced. Examples of these studies include those of Fields and Jakubson (1994), Fishlow (1972), Deineger and Squire (1998) and Barreto, Melo Neto and Tebaldi (2001).

According to Stewart (2000) and Fosu (2010), a high level of income inequality gives rise to political instability, uncertainty, less investment, slower growth and populist redistributive tax policies. Deterrence effects and greater inequality influence the richer strata of society, which press for preferential tax treatment. This, in turn, leads to over-investment in certain areas and curbs growth.

Easterly (2000) and Adams (2004) analysed the relationships between growth and income inequality across countries and observed that the growth elasticity of poverty is greater in countries with lower Gini coefficients (less inequality). These authors underscore the importance of a reduction in inequality in determining the response capacity of poverty to rising income levels.

On the other hand, studies such as those of Li and Zou (1998) and Forbes (2000), which used five-year means for 35-country samples, indicate that, when panel data are employed, the negative 
relationship between growth and inequality disappears. Barro (2000) suggests that the negative impact of inequality on growth depends on how wealthy a country is, although this relationship is not robust.

Castelar (2007) analysed the relationship between growth and inequality in the states of Brazil on the basis of panel data for 1985-2002. Using the two-step Arellano and Bond estimator, he found that income inequality depresses economic growth and was able to corroborate the convergence hypothesis, according to which initially low income or output levels are correlated with higher growth rates.

In an analysis of Brazil, Ferreira and Cruz (2010) use a threshold-effect model to study the existence of income-inequality convergence clubs at the municipal level in 1991-2000. These authors detected six such clubs, with the factors that reduced the inequality of income distribution in the municipalities of Brazil having asymmetric effects. In the course of this convergence process, labour income was more influential than income derived from government transfers in the reduction of inequality.

\section{Data source and description}

The database used here includes information on 25 federation units (i.e. 24 states and the federal district) for 1981-2013. ${ }^{3}$ All the data have been taken from the National Household Survey (PNAD) conducted by the Brazilian Geographical and Statistical Institute (IBGE).

The income variable is per capita household income $(R M)$ and is estimated on the basis of the ratio between total household income and the number of members of the household. We then calculate the arithmetic mean of that variable in order to obtain the mean income for each state and the federal district. ${ }^{4}$

Families whose per capita household incomes fall short of the sums needed to meet their basic needs are classified as poor. As an absolute poverty indicator, the metric proposed by Foster, Greer and Thorbecke (1984), known as the poverty headcount index $\left(P_{0}\right)$, is used. This index is defined as follows:

$$
P(\alpha)=\int_{0}^{P L}\left(\frac{P L-y}{P L}\right)^{\alpha} f(y) d y
$$

For the poverty headcount index $\left(P_{o}\right), \alpha=0$, the poverty line $(P L)$ employed by the Institute of Applied Economic Research (IPEA $)^{5}$ is used, while for the extreme poverty headcount index, $\alpha=e x t$, the extreme poverty line $\left(P_{\text {ext }}\right)$ is used. ${ }^{6}$

3 Since the period of analysis stretches from 1981 to 2013, the data for the State of Tocantins, which was established in 1990, were combined with those for the State of Goiás. Thus, the calculations for income and for poverty and inequality indices for the years from 1990 on were performed by grouping the data for those two states. In addition, since the National Household Survey was not conducted in 1994 or in 2000 , an interpolation of the arithmetic means for the preceding and following years was used.

4 All of the monetary variables have been updated to reflect real 2013 values using the national consumer price index for October 2013 as a deflator.

5 The poverty line being used here is two times the extreme poverty line.

6 The extreme poverty line being used here is an estimate of the value of a food basket representing the minimum number of calories needed to sustain a person according to the recommended levels issued by the United Nations Food and Agriculture Organization (FAO) and the World Health Organization (WHO). The series is calculated on the basis of responses to the National Household Survey (PNAD/IBGE). For further details, see www.ipeadata.gov.br. 
The Gini coefficient $(G)$ is used as the metric for income inequality. ${ }^{7}$ In order to calculate this coefficient, per capita household incomes have to be placed in ascending order to obtain the Lorenz curve, which plots the cumulative percentage of the population against the cumulative percentage of income for each percentile. The Gini coefficient for each state and for the federal district can then be calculated from these data. ${ }^{8}$

Table 1 shows that the mean poverty headcount index $\left(P_{0}\right)$ was 0.3992 for the period under analysis, while the lowest and highest values were 0.0167 and 0.8616 , respectively. In other words, $39.92 \%$ of the Brazilian population was below the poverty line used in this study, while $17.76 \%$ of these people were living in extreme poverty.

Mean per capita household income in 1981-2013 was 571.76 reais. The lowest amount to be registered, 160.13 reais, was for Piauí in 1983, while the highest, 1,266.63 reais was for São Paulo in 2012. The mean value for inequality (expressed in terms of the Gini coefficient) was 0.5585 , with the range running from 0.3933 (Roraima in 1983) to 0.6665 (Piauí in 1990).

Table 1

Brazil: descriptive statistics for all states, 1981-2013

\begin{tabular}{lccccc}
\hline Variables & Observations & Mean & Standard deviation & Lowest & Highest \\
\hline Poverty headcount index $\left(P_{0}\right)$ & 800 & 0.3992 & 0.1885 & 0.0167 & 0.8616 \\
\hline $\begin{array}{l}\text { Extreme poverty headcount } \\
\text { index }\left(P_{\text {ext }}\right)\end{array}$ & 800 & 0.1776 & 0.1309 & 0.0071 & 0.6279 \\
\hline Per capita household income $(R m)$ & 800 & 571.76 & 225.56 & 160.13 & 1266.63 \\
\hline Gini coefficient $(G)$ & 800 & 0.5585 & 0.0440 & 0.3933 & 0.6665 \\
\hline
\end{tabular}

Source: Prepared by the authors.

\section{The econometric model}

In order to quantify the effects of economic growth and income inequality in terms of poverty, a dynamic panel data model is used:

$$
\ln \left(P_{k, i t}\right)=\beta_{0}+\beta_{1} \ln \left(P_{k, i t-1}\right)+\beta_{2} \ln \left(R m_{i, t}\right)+\beta_{3} \ln \left(G_{i, t}\right)+v_{t}+u_{i, t}
$$

Where $P_{k, i t}$ represents the poverty index $k$ based on the poverty line (i.e. $k=0$ for the poverty headcount index and $k=e x t$ for the extreme poverty headcount index); $R m_{i, t}$ corresponds to mean per capita income; $G_{i, t}$ is the Gini coefficient; $v_{t}$ stands for the unobservable fixed effects for individuals; and $u_{i, t}$ is the idiosyncratic error term. The $i$ and $t$ subindices refer to the federation unit (state or federal district) and the year.

The model is specified by logarithms that yield the income and inequality elasticities of poverty, which are represented by the coefficients $\beta_{2}$ and $\beta_{3}$, respectively.

The specification of the model (2) is based on the assumption that the existing level of poverty tends to influence poverty dynamics. This justifies the introduction of a one-period lagged independent variable $\left(P_{k, i t-1}\right)$ as an explanatory variable. ${ }^{9}$

The hypotheses for the model are that $E\left[v_{i}\right]=E\left[u_{i, t}\right]=E\left[v_{i} u_{i, t}\right]=0$ for $i=1, \ldots, N$ and $t=1, \ldots, T$; the error is not temporally correlated or, in other words, $E\left[u_{i, T} u_{i, S}\right]=0$ for $i=1, \ldots, N$ and

\footnotetext{
7 According to Litchfield (1999), this index fulfils four of the five axioms that inequality measures are generally required to meet: the Pigou-Dalton transfer principle, the income scale independence principle, the principle of population and the symmetry (or anonymity) principle. The axiom that it does not meet is the additive decomposability principle.

8 The Gini coefficient ranges from 0 (zero) to 1 (one). The closer it is to 1 , the greater the degree of income inequality, while the closer it is to zero, the less inequality there is (Hoffmann, 1998).

9 For evidence regarding the perpetuation of poverty in Brazil, see Ribas, Machado and Golgher (2006).
} 
$\forall t \neq s$. In addition, the initial condition of $E\left[P_{k, i t} u_{i, t}\right]=0$ for $i=1, \ldots, N$ and $t=1, \ldots, T$ is imposed (Ahn and Schmidt, 1995).

An observation regarding the problem of endogeneity is called for here. Figueiredo and Laurini (2015) voice concern about the possibility of endogeneity being a factor when the usual Ravallion and Chen (1997) methodology is used to measure the effects of economic growth on poverty and inequality. According to these authors, this can arise as a result of two mechanisms: the simultaneous determination of poverty and growth, which could generate a correlation with the error component (endogeneity problems can be caused by unobserved factors that affect these two components simultaneously or by a financial development process that simultaneously affects poverty, growth and inequality); or the direct effect that a growth trend could have on the poverty measurement.

Another problem that can bias the estimates and that has also been pointed out by Figueiredo and Laurini (2015) has to do with the functional form used for the relationship between poverty, growth and inequality. With linear specifications, it is assumed that the effects of growth on poverty and inequality are constant and independent of the levels of growth and inequality. However, a number of studies on the subject have raised questions in this regard, with their authors arguing that hypothesizing a linear relationship between growth, inequality and poverty can produce a misspecification that biases the estimates because these relationships may not, in fact, be linear.

The presence of $P_{k, i t-1}$ as an explanatory variable in equation (2) can give rise to endogeneity ${ }^{10}$ and produce a bias in the dynamic panel. In that case, the OLS estimates will tend to be biased and inconsistent, overestimating the coefficient of that variable. An effort can be made to correct this bias by using the fixed effects estimator (within-groups), which generates slightly smaller standard deviations of the coefficients. However, in order to solve the problem of endogeneity, a first-differences transformation should be applied, after which an estimate can be made using the generalized method of moments (GMM) while minimizing the moment conditions of the distribution. Using this approach, equation (2) becomes:

$$
\Delta \ln \left(P_{k, i t}\right)=\beta_{1} \Delta \ln \left(P_{k, i t-1}\right)+\beta_{2} \Delta \ln \left(R m_{i, t}\right)+\beta_{3} \Delta \ln \left(G_{i, t}\right)+\Delta u_{i, t}
$$

where $\Delta$ is an operator of differences and, given equation (3), $\Delta \ln \left(P_{k, i t-1}\right)$ and $\Delta u_{i, t}$ are correlated and the endogeneity persists. It thus becomes necessary to use some instrument for $\Delta \ln \left(P_{k, i t-1}\right)$. The hypotheses adopted in equation (2) imply that the moment conditions $E\left[\Delta \ln \left(P_{k, i t-s} \Delta u_{i t}\right)\right]=0$ for $t=3,4, \ldots, T$ and $s \geq 2$ are valid. In line with those moments, Arellano and Bond (1991) suggest that $\Delta \ln \left(P_{k, i t-s}\right)$ be used for $t=3,4, \ldots, T$ and $s \geq 2$ as instruments for equation (3).

In the second case, the values of the variable that is lagged one or more periods can be regarded as valid instruments for estimating equation (3). In the last case, the values of the variables that are lagged two or more periods are valid instruments for estimating equation (2).

However, Arellano and Bover (1995) and Blundell and Bond (1998) explain that these instruments are weak when the dependent and explanatory variables exhibit a high degree of persistence, when the relative variance of the fixed effects increases or when both of these things occur. In this case, the estimator is inconsistent and biased. To solve this problem, these authors recommend estimating a system that combines the equations in differences (equation (3)) with the equations in levels (equation (2)), i.e. the system GMM.

\footnotetext{
10 In the event that the explanatory variables of the model are correlated with the residuals $E\left(Z_{i t}, \varepsilon_{i t}\right) \neq 0$. Any given variable can be classified as: strictly exogenous, if it is not correlated with the past, present and future error terms; weakly exogenous, if it is correlated only with the past values of the error term; or endogenous, if it is correlated with the past, present and future error terms.
} 
For the equations in differences, the instruments are the same as those described earlier, whereas, for the regression in levels, the appropriate instruments are the lagged differences of the corresponding variables. For example, assuming that the differences of the explanatory variables are not correlated with the individual fixed effects (for $t=3,4, \ldots, T)$ and $E\left[\Delta \ln \left(P_{k, i 2} v_{i}\right)\right]=0$ for $i=1,2,3, \ldots, N$, the explanatory variables in differences and $\Delta \ln \left(P_{k, i t-1}\right)$, in the event that they are exogenous or weakly exogenous, are valid instruments for the equation in levels. The same is true if they are endogenous, but the instruments are then the explanatory variables in differences lagged one or more periods $\Delta \ln \left(P_{k, i t-1}\right)$.

The consistency of the system-GMM estimator depends on the absence of a serial correlation in the error term and the validity of the additional instruments. Initially, the null hypotheses of absence of autocorrelation of first and second order of the residual series need to be tested. In order for the estimators for the parameters to be consistent, the hypothesis of absence of autocorrelation of first order must be rejected and that of second order must be accepted. The Hansen and Sargan tests can then be run to check the validity of the instruments used in the system GMM.

Since the OLS estimator for the lagged dependent variable theoretically yields downward biased estimates, whereas the within-group estimators generate upward biased estimates, the appropriate estimate of the parameter of $\ln \left(P_{k, i t-1}\right)$ should be somewhere between the two (OLS and within group).

Following this description of the econometric and statistical procedures for arriving at these estimates, the next section presents an analysis and discussion of the results obtained using the system-GMM method to ensure that the variances of the parameters are robust to heteroscedasticity and autocorrelation. The estimator obtained by that means was corrected using the method developed by Windmeijer (2005) to avoid underestimating the true variances in the finite sample.

\section{Analysis and discussion of the results}

The period 1981-2013 was chosen for the comparison of the income and inequality elasticities of poverty, along with the subperiods 1981-1994 and 1995-2013, so that the values for these elasticities in the years prior to and following the implementation of the Real Plan and in different stages in the economic development process of Brazil could be analysed.

First of all, equation (2) was estimated using OLS and the within-group method $\ln \left(R m_{i, t}\right)$. In selecting the estimated model, account was taken of the results of the Hausman specification tests to check whether $R m_{i, t}$ and $G_{i, t}$ are endogenous and the results of the Hansen and Sargan tests of the instruments' validity. These tests showed that the $R m_{i, t}$ and $G_{i, t}$ variables did not have to be treated as endogenous variables and that the use of the second lags of the variables and the additional instruments required by the system GMM are valid.

Tests were also run to detect the presence of autocorrelation of first order of the residuals in level and in first difference (i.e. second order). The results of these tests are shown in tables 2, 3 and 4. None of the estimates rejects the null hypothesis, so the residuals exhibit a first-order correlation. In order to prevent the estimates from being biased, it is necessary to mitigate their presence. One of the ways of doing this is to estimate the model in first difference using, for example, the systemGMM estimator.

Consequently, the estimates obtained using the system-GMM method are taken into account in the analysis of the results. Tables 2, 3 and 4 show the results for the selected models that were estimated using OLS and the within-group method for the poverty headcount index $\left(P_{0}\right)$ and extreme 
poverty headcount index $\left(P_{\text {ext }}\right)$ in Brazil. The OLS and within-group estimates are given only as a means of showing that the estimated value of the lagged dependent variable falls between the estimated values obtained using these two methods. This may be viewed as an indication that the bias generated by the presence of endogenous variables and unobservable fixed effects has been corrected for by using the system-GMM method.

\section{1981-2013}

Table 2 shows the income and inequality elasticities for poverty and extreme poverty based on the corresponding headcount indices for the period 1981-2013. The results appear to confirm the hypothesis concerning poverty persistence, given the statistical significance of the variable $\ln \left(P_{k, i t-1}\right)$. In this regard, our figures corroborate the presence of poverty persistence as measured by the poverty headcount index ${ }^{11}\left(0.1025\right.$ for $\left.P_{0}\right)$ and even more so in the case of the extreme poverty headcount index ( 0.1356 for $\left.P_{\text {ext }}\right)$. These results indicate that, while no steep upturn in poverty has been observed, poverty persistence is indeed a reality in the states of Brazil, ${ }^{12}$ and they thus provide corroboration for the findings of Ribas, Machado and Golgher (2006), Marinho and Araújo (2010) and Marinho, Linhares and Campelo (2011).

Two of the determinants that have played a significant role in the reduction of poverty are mean per capita household income and the level of inequality as measured by the Gini coefficient.

The estimated coefficients of the income elasticity of poverty showed the expected (negative) signs, since increases in mean per capita household incomes lower poverty levels. The values of these coefficients were -0.9235 for $P_{0}$ and -1.1418 for $P_{\text {ext }}$. This means that a $10 \%$ increase in mean per capita household income in Brazil will translate into a $9.23 \%$ reduction in the poverty headcount index and in an $11.41 \%$ decline in the extreme poverty headcount index.

In line with the definitions used by Kakwani and Pernia (2000), the income elasticities of poverty appear to indicate that growth in Brazil has been pro-poor only in the case of extreme poverty, for which the estimated coefficient is greater than 1 (in absolute terms). In other words, the decrease in extreme poverty levels has outstripped the increase in income levels. However, in line with the definitions used by Ravallion and Chen (2003), growth has been pro-poor for both the poor and the extremely poor segments of the population, since growth has reduced poverty levels.

The estimated coefficients for the inequality elasticity of poverty also show the expected (positive) signs, as the decrease in inequality (as measured by the Gini coefficient) lowers poverty levels. The values of these coefficients were 1.9470 for $P_{0}$ and 2.8912 for $P_{\text {ext }}$. In other words, a 10\% decrease in income inequality translates into a $19.47 \%$ reduction in the poverty headcount index and a drop of $28.91 \%$ in the extreme poverty headcount index in Brazil.

Another important finding is that the repercussions of the income effect and of the inequality effect are greater in the case of the extreme poverty headcount than they are in that of the poverty headcount. This is because, since the extreme poverty line is lower than the poverty line, it is more sensitive to upward movements in income levels and reductions in the level of inequality.

\footnotetext{
11 Statistically significant at $1 \%$.

${ }^{12}$ According to Rocha (2006), the high poverty rate in Brazil is primarily associated with the poor distribution of resources among the country's inhabitants.
} 
Table 2

Brazil: estimated values for the poverty headcount index and the extreme poverty headcount index, 1981-2013

\begin{tabular}{|c|c|c|c|c|c|c|}
\hline \multirow[b]{2}{*}{ Explanatory variables } & \multicolumn{3}{|c|}{ Poverty $\left(\mathrm{LnP}_{0}\right)$} & \multicolumn{3}{|c|}{ Extreme poverty $\left(\mathrm{LnP}_{\text {ext }}\right)$} \\
\hline & $\begin{array}{l}\text { Ordinary least } \\
\text { squares }\end{array}$ & Within-group & GMM system & $\begin{array}{l}\text { Ordinary least } \\
\text { squares }\end{array}$ & Within-group & GMM system \\
\hline $\ln P_{0, i t-1}$ & $\begin{array}{c}0.2001^{*} \\
(0.0255)\end{array}$ & $\begin{array}{l}0.0862^{*} \\
(0.0247)\end{array}$ & $\begin{array}{c}0.1025^{\star} \\
(0.0385)\end{array}$ & $\begin{array}{c}0.3596^{\star} \\
(0.0231)\end{array}$ & $\begin{array}{l}0.1254^{*} \\
(0.0208)\end{array}$ & $\begin{array}{l}0.1356^{\star} \\
(0.0252)\end{array}$ \\
\hline $\ln R m_{i t}$ & $\begin{array}{l}-0.6732^{*} \\
(0.0311)\end{array}$ & $\begin{array}{l}-0.9476^{*} \\
(0.0325)\end{array}$ & $\begin{array}{l}-0.9235^{\star} \\
(0.1130)\end{array}$ & $\begin{array}{l}-1.0271^{*} \\
(0.0418)\end{array}$ & $\begin{array}{l}-1.3882^{*} \\
(0.0388)\end{array}$ & $\begin{array}{r}-1.1418^{*} \\
(0.0705)\end{array}$ \\
\hline $\ln G_{i t}$ & $\begin{array}{l}1.3401^{*} \\
(0.1065)\end{array}$ & $\begin{array}{l}2.0793^{*} \\
(0.1069) \\
\end{array}$ & $\begin{array}{l}1.9470^{*} \\
(0.2364) \\
\end{array}$ & $\begin{array}{l}2.1421 \text { * } \\
(0.1334)\end{array}$ & $\begin{array}{l}3.2094^{*} \\
(0.1224)\end{array}$ & $\begin{array}{l}2.8912^{*} \\
(0.2352) \\
\end{array}$ \\
\hline Constant & $\begin{array}{l}4.3633^{*} \\
(0.1895) \\
\end{array}$ & $\begin{array}{r}6.3059^{*} \\
(0.1985)\end{array}$ & $\begin{array}{r}6.0746^{*} \\
(0.6982) \\
\end{array}$ & $\begin{array}{c}6.3827^{*} \\
(0.2426)\end{array}$ & $\begin{array}{l}8.8043^{*} \\
(0.2282)\end{array}$ & $\begin{array}{r}8.3485^{\star} \\
(0.4189) \\
\end{array}$ \\
\hline F statistic & 2262.58 & 1382.37 & 127.22 & 3156.57 & 2055.37 & 410.18 \\
\hline$p$-value & 0.0000 & 0.0000 & 0.0000 & 0.0000 & 0.0000 & 0.0000 \\
\hline$R^{2}$ & 0.8975 & - & - & 0.9306 & - & - \\
\hline N & 775 & 775 & 775 & 775 & 775 & 775 \\
\hline Groups & 25 & 25 & 25 & 25 & 25 & 25 \\
\hline $\begin{array}{l}\mathrm{H}_{0} \text { : absence of autocorrelation } \\
\text { in residuals of first order }\end{array}$ & & $p$-value & 0.012 & & 0.026 & \\
\hline $\begin{array}{l}\mathrm{H}_{0} \text { : absence of autocorrelation } \\
\text { in residuals of second order }\end{array}$ & & $p$-value & 0.241 & & 0.921 & \\
\hline Hansen test & & Prob>chi2 & 0.450 & & 0.367 & \\
\hline Sargan test & & Prob>chi2 & 0.637 & & 0.621 & \\
\hline
\end{tabular}

Source: Prepared by the authors.

Note: $\quad$ * denotes statistical significance at $1 \%$.

In addition, the value of the coefficient for the inequality elasticity of poverty is higher (in absolute terms) than the coefficient for the income elasticity of poverty in the case of both the poverty headcount index and the extreme poverty headcount index. This points to the possibility that the effects which reductions in inequality have in terms of decreases in poverty levels may be greater than the effects of increases in mean income levels. One possible explanation for this is that increases in income levels are transmitted to the poor segment of the population in the region in a disproportionate (or unequal) manner. These results are similar to those obtained by França (2010).

Along these same lines, Ravallion (1997 and 2004), Marinho and Soares (2003), Bourguignon (2002), López and Seven (2004), Menezes and Pinto (2005), Barreto, França and Oliveira (2008) and Marinho, Linhares and Campelo (2011) all contend that growth-oriented anti-poverty policies would be more effective if they were coupled with income redistribution measures.

As noted in the Introduction, the main contribution made by this study is its analysis of the effects of economic growth and income inequality on poverty levels in Brazil during different periods: the years leading up to the introduction of the Real Plan, when inflation was endemic in the country; and the years following its implementation, when prices stabilized. This analysis is presented in the following sections.

\section{Before the Real Plan (1981-1994)}

Table 3 shows the results for the selected models that were estimated using OLS, the within-group method and the system-GMM method for the poverty headcount index $\left(P_{0}\right)$ and the extreme poverty headcount index $\left(P_{\text {ext }}\right)$ in Brazil for the period leading up to the Real Plan. 
Here again, the poverty persistence hypothesis appears to be confirmed, given the statistical significance of the variable $\ln \left(P_{k, i t-1}\right)$, with the degree of persistence being quite high in relation to the poverty headcount index $\left(0.1212\right.$ for $\left.P_{0}\right)$ and somewhat less so in the case of the extreme poverty headcount index $\left(0.1230\right.$ for $\left.P_{\text {ext }}\right)$. These results indicate that, while poverty has not trended steeply upward in the various states that make up Brazil, it has been persistent.

As is also true for the entire period under study, the results for this subsample support the conclusion that increases in mean per capita household income and decreases in inequality as reflected in the Gini coefficient, which have been considered here as the determinants of poverty, have indeed made a significant contribution to the reduction in poverty levels.

By the same token, as mentioned in the preceding section, the coefficients for the income elasticity of poverty were negative, as expected, since increases in mean per capita household incomes reduce poverty levels. These coefficients were -0.7813 for $P_{0}$ and 0.8607 for $P_{\text {ext }}$. This means that a $10 \%$ rise in mean per capita household income in Brazil will translate into a $7.81 \%$ reduction in the poverty headcount index and an $8.61 \%$ drop in the extreme poverty headcount index. While for Kakwani and Pernia (2000), this does not constitute pro-poor growth, it does qualify as propoor growth when using the definitions advocated by Ravallion and Chen (2003), since growth has lowered poverty levels.

The estimated coefficients for the inequality elasticity of poverty are, here again, positive, as declines in inequality, as reflected in the Gini index, reduce poverty. These coefficients were 1.7487 for $P_{0}$ and 2.6541 for $P_{\text {ext }}$. In other words, a 10\% decrease in income inequality translates into a $17.49 \%$ drop in the poverty headcount index and a $26.54 \%$ decrease in the extreme poverty headcount index in Brazil.

As before, the repercussions of the income effect and the inequality effect are greater in the case of the extreme poverty headcount index $\left(P_{\text {ext }}\right)$ than in that of the poverty $\left(P_{0}\right)$.

Table 3

Brazil: estimated values for the poverty headcount index and the extreme poverty headcount index, 1981-1994

\begin{tabular}{|c|c|c|c|c|c|c|}
\hline \multirow[b]{2}{*}{ Explanatory variables } & \multicolumn{3}{|c|}{ Poverty $\left(\mathrm{LnP}_{0}\right)$} & \multicolumn{3}{|c|}{ Extreme poverty $\left(\mathrm{LnP}_{\text {ext }}\right)$} \\
\hline & $\begin{array}{l}\text { Ordinary least } \\
\text { squares }\end{array}$ & Within-group & GMM-system & $\begin{array}{l}\text { Ordinary least } \\
\text { squares }\end{array}$ & Within-group & GMM-system \\
\hline $\ln P_{0, i t-1}$ & $\begin{array}{r}0.0353^{*} \\
(0.0168)\end{array}$ & $\begin{array}{c}0.1493^{\star} \\
(0.0211)\end{array}$ & $\begin{array}{c}0.1212^{\star} \\
(0.0264)\end{array}$ & $\begin{array}{c}0.1607^{\star} \\
(0.0330)\end{array}$ & $\begin{array}{l}0.0495^{\star \star \star} \\
(0.0282)\end{array}$ & $\begin{array}{l}0.1230^{\star} \\
(0.0421)\end{array}$ \\
\hline $\ln R m_{i t}$ & $\begin{array}{l}-0.9131^{*} \\
(0.0411)\end{array}$ & $\begin{array}{l}-1.1542^{*} \\
(0.0511)\end{array}$ & $\begin{array}{l}-0.7813^{*} \\
(0.0705)\end{array}$ & $\begin{array}{l}-1.2910^{\star} \\
(0.0581)\end{array}$ & $\begin{array}{l}-1.7918^{*} \\
(0.0630)\end{array}$ & $\begin{array}{c}-0.8607^{\star} \\
(0.0791)\end{array}$ \\
\hline $\ln G_{i t}$ & $\begin{array}{c}1.5575^{\star} \\
(0.1483)\end{array}$ & $\begin{array}{l}2.2704 \text { * } \\
(0.1535)\end{array}$ & $\begin{array}{l}1.7487^{*} \\
(0.3864)\end{array}$ & $\begin{array}{l}2.1949^{\star} \\
(0.1912)\end{array}$ & $\begin{array}{l}3.4138 * \\
(0.1883)\end{array}$ & $\begin{array}{l}2.6541^{*} \\
(0.2532)\end{array}$ \\
\hline Constant & $\begin{array}{l}5.6512^{*} \\
(0.2458)\end{array}$ & $\begin{array}{l}8.6960^{\star} \\
(0.3363) \\
\end{array}$ & $\begin{array}{l}6.2928^{*} \\
(0.5381) \\
\end{array}$ & $\begin{array}{l}7.6854 * \\
(0.3349)\end{array}$ & $\begin{array}{c}11.2595^{*} \\
(0.4100)\end{array}$ & $\begin{array}{l}8.8164^{*} \\
(0.4758) \\
\end{array}$ \\
\hline F statistic & 626.03 & 281.22 & 83.17 & 991.05 & 374.07 & 180.89 \\
\hline$p$-value & 0.0000 & 0.0000 & 0.0000 & 0.0000 & 0.0000 & 0.0000 \\
\hline $\mathrm{R}^{2}$ & 0.8543 & - & - & 0.9051 & - & - \\
\hline N & 325 & 325 & 325 & 325 & 325 & 325 \\
\hline Groups & 25 & 25 & 25 & 25 & 25 & 25 \\
\hline \multicolumn{2}{|c|}{$\begin{array}{l}\mathrm{H}_{0} \text { : absence of autocorrelation } \\
\text { in residuals of first order }\end{array}$} & $p$-value & 0.040 & & 0.013 & \\
\hline \multicolumn{2}{|c|}{$\begin{array}{l}\mathrm{H}_{0} \text { : absence of autocorrelation } \\
\text { in residuals of second order }\end{array}$} & $p$-value & 0.134 & & 0.892 & \\
\hline \multicolumn{2}{|l|}{ Hansen test } & Prob>chi2 & 0.369 & & 0.425 & \\
\hline \multicolumn{2}{|l|}{ Sargan test } & Prob>chi2 & 0.425 & & 0.538 & \\
\hline
\end{tabular}

Source: Prepared by the authors.

Note: * and ${ }^{* \star *}$ denote statistical significance at $1 \%$ and $10 \%$, respectively. 


\section{After the Real Plan (1995-2013)}

Table 4 shows the results for the selected models that were estimated using OLS, the within-group method and the system-GMM method for the poverty headcount index $\left(P_{0}\right)$ and the extreme poverty headcount index $\left(P_{\text {ext }}\right)$ in Brazil for the years following the Real Plan.

The poverty persistence hypothesis is confirmed in this case, too, given the statistical significance of the variable $\ln \left(P_{k, i t-1}\right)$. Here again, the degree of persistence is high for the poverty headcount index $\left(0.7690\right.$ for $\left.P_{0}\right)$ and less so for the extreme poverty headcount index $(0.5905$ for $\left.P_{\text {ext }}\right)$. These results, like those obtained for the period as a whole and for the subsample for the years prior to the Real Plan, indicate that poverty in the states of Brazil has been persistent but has not risen sharply.

As in the other cases, mean per capita household income and the Gini index also made a significant contribution to reductions in poverty in the years following the Real Plan.

The estimated coefficients for the income elasticity of poverty are negative in this case as well, thereby corroborating the finding that increases in mean per capita household income reduce poverty. These coefficients were -1.1560 for $P_{0}$ and -1.3410 for $P_{\text {ext }}$. In other words, a $10 \%$ upturn in mean per capita household income in Brazil translates into an $11.56 \%$ reduction in the poverty headcount index and a $13.41 \%$ drop in the extreme poverty headcount index. Consequently, in this case, growth is shown to be pro-poor both for poor segments and extremely poor segments of the population, and this holds true regardless of whether the definitions espoused by Kakwani and Pernia (2000) or those proposed by Ravallion and Chen (2003) are used.

The estimated coefficients for the inequality elasticity of poverty are positive, as expected, which means that a decline in inequality (as measured by the Gini index) reduces poverty levels. These coefficients were 2.0564 for $P_{0}$ and 2.2508 for $P_{\text {ext }}$. In other words, a 10\% decrease in income inequality translates into a $20.56 \%$ reduction in the poverty headcount index and a drop of $22.50 \%$ in the extreme poverty headcount index for Brazil.

As has also been shown to be true for the period under study as a whole and for the period 1981-1994, the repercussions of the income effect and the inequality effect are greater in relation to the extreme poverty headcount index than they are for the poverty headcount index $\left(P_{0}\right)$.

The explanation for this, as noted earlier, is that, since the extreme poverty line is lower that the poverty line, it is therefore more sensitive to upward movements in income levels. In short, all the results for both subperiods (the years leading up to the Real Plan, which were marked by spiraling inflation, and the years that followed it, when inflation rates were low and stable) are similar and fit in with the results obtained for the study period as a whole. Nonetheless, the income and inequality elasticities of poverty, both for the poverty and extreme poverty headcount indices, are lower (in absolute values) for the pre-Real Plan period that for the other two periods that have been analysed.

This is probably attributable to the instability that plagued the Brazilian economy in the 1980s, when high inflation was coupled with slow growth. In this kind of situation, poverty levels were less sensitive to changes in the levels of income and inequality.

As was to be expected, the results also indicate that decreases in inequality may have a greater effect in terms of reductions in poverty rates than increases in mean income levels do. Again, one possible explanation for this is that upswings in income levels are transmitted disproportionately or unequally to the poor segments of the population. In other words, income transfer policies have not been focused on the most underprivileged members of society. 
Table 4

Brazil: estimated values for the poverty headcount index and the extreme poverty headcount index, 1981-2012

\begin{tabular}{|c|c|c|c|c|c|c|}
\hline \multirow[b]{2}{*}{ Explanatory variables } & \multicolumn{3}{|c|}{ Poverty (LnPo) } & \multicolumn{3}{|c|}{ Extreme poverty $\left(\mathrm{LnP}_{\text {ext }}\right)$} \\
\hline & $\begin{array}{l}\text { Ordinary least } \\
\text { squares }\end{array}$ & Within-group & GMM-system & $\begin{array}{l}\text { Ordinary least } \\
\text { squares }\end{array}$ & Within-group & GMM-system \\
\hline $\ln P_{0, i t-1}$ & $\begin{array}{c}0.8834^{*} \\
(0.0243)\end{array}$ & $\begin{array}{l}0.6641^{*} \\
(0.0306)\end{array}$ & $\begin{array}{l}0.7690^{*} \\
(0.0656)\end{array}$ & $\begin{array}{c}0.6948^{\star} \\
(0.0306)\end{array}$ & $\begin{array}{l}0.3068^{*} \\
(0.0356)\end{array}$ & $\begin{array}{l}0.5905^{\star} \\
(0.0613)\end{array}$ \\
\hline $\ln R m_{i t}$ & $\begin{array}{l}-0.7596^{*} \\
(0.0333)\end{array}$ & $\begin{array}{l}-0.8641^{*} \\
(0.0398)\end{array}$ & $\begin{array}{l}-1.1560^{*} \\
(0.0739)\end{array}$ & $\begin{array}{l}-0.9371^{*} \\
(0.0578)\end{array}$ & $\begin{array}{l}-1.0503^{*} \\
(0.0651)\end{array}$ & $\begin{array}{l}-1.3410^{*} \\
(0.1044)\end{array}$ \\
\hline $\ln G_{i t}$ & $\begin{array}{l}0.6444^{*} \\
(0.0971)\end{array}$ & $\begin{array}{l}1.3040^{*} \\
(0.1149)\end{array}$ & $\begin{array}{l}2.0564^{*} \\
(0.3547)\end{array}$ & $\begin{array}{l}1.5687^{\star} \\
(0.1686)\end{array}$ & $\begin{array}{l}2.9973^{\star} \\
(0.1797)\end{array}$ & $\begin{array}{l}2.2508^{*} \\
(0.2387) \\
\end{array}$ \\
\hline Constant & $\begin{array}{l}1.2597^{*} \\
(0.2014)\end{array}$ & $\begin{array}{l}2.9136^{*} \\
(0.2360)\end{array}$ & $\begin{array}{l}2.0740^{*} \\
(0.4853)\end{array}$ & $\begin{array}{l}3.2547^{*} \\
(0.3391)\end{array}$ & $\begin{array}{l}6.2843^{*} \\
(0.2739)\end{array}$ & $\begin{array}{l}4.2841^{*} \\
(0.6008)\end{array}$ \\
\hline F statistic & 4664.63 & 1781.79 & 1090.76 & 3025.40 & 1319.33 & 1050.62 \\
\hline$p$-value & 0.0000 & 0.0000 & 0.0000 & 0.0000 & 0.0000 & 0.0000 \\
\hline $\mathrm{R}^{2}$ & 0.9708 & - & - & 0.9557 & - & - \\
\hline N & 425 & 425 & 425 & 425 & 425 & 425 \\
\hline Groups & 25 & 25 & 25 & 25 & 25 & 25 \\
\hline \multicolumn{2}{|c|}{$\begin{array}{l}\mathrm{H}_{0} \text { : absence of autocorrelation } \\
\text { in residuals of first order }\end{array}$} & $p$-value & 0.008 & & 0.011 & \\
\hline \multicolumn{2}{|c|}{$\begin{array}{l}\mathrm{H}_{0} \text { : absence of autocorrelation } \\
\text { in residuals of second order }\end{array}$} & $p$-value & 0.805 & & 0.496 & \\
\hline \multicolumn{2}{|l|}{ Hansen test } & Prob>chi2 & 0.762 & & 0.453 & \\
\hline \multicolumn{2}{|l|}{ Sargan test } & Prob>chi2 & 0.835 & & 0.792 & \\
\hline
\end{tabular}

Source: Prepared by the authors.

Note: $\quad$ *denotes statistical significance at $1 \%$.

\section{Concluding remarks}

This study has analysed the effects of economic growth and income inequality on poverty in Brazil between 1981 and 2013 using a dynamic panel data methodology and two measurements of poverty: the poverty and the extreme poverty headcount indices. Three periods were studied: the first runs from 1981 to 2013, while the second and third correspond to the stages prior to and following the implementation of the Real Plan (1981-1994 and 1995-2013, respectively).

The estimates arrived at using the OLS, within-group and system-GMM methods confirm the presence of persistent poverty dynamics and provide support for the statement that this phenomenon is primarily associated with the poor distribution of income in Brazilian society.

An analysis of the situation during the years leading up to the Real Plan (1981-1994) indicates that the income and inequality elasticities of poverty, as measured by both the poverty and the extreme poverty headcount indices, were lower (in absolute terms) than they were in the other two periods that were studied. This is probably due to the instability observed in the Brazilian economy in the 1980s. The combination of high inflation and a slow pace of growth in income during that decade can be identified as the reason why poverty levels became less sensitive to changes in income and inequality levels.

The analysis of the income elasticity of poverty indicates that growth was pro-poor in 19812013 according to the definition employed by Kakwani and Pernia (2000) of that term, but only in the case of extreme poverty. This means that income increased more than poverty declined. When the definition developed by Ravallion and Chen (2003) is used, then growth was pro-poor in all the periods that were studied as measured both by the poverty and the extreme poverty headcount indices. 
Although, regardless of the definition used, growth was not pro-poor during the subperiod preceding the Real Plan, it was indeed pro-poor for both the poor and the extremely poor segments of the population in the subperiod that followed the implementation of the Plan. This result can be attributed to the economic stability seen during those years, the real increase in the minimum wage and the implementation of direct income transfer policies (França, 2010; Kakwani, Neri and Son, 2010).

The values obtained when the income and inequality elasticities of poverty were estimated indicate that policies aimed at boosting mean per capita household income and policies designed to reduce inequality tend to lower both poverty and extreme poverty levels. The results also indicate that these policies are more effective in reducing the extreme poverty headcount than the poverty headcount because, since the extreme poverty line is lower than the poverty line, it is more sensitive to policy measures.

A decline in inequality has a greater effect in terms of reductions in the extreme poverty and poverty headcounts than policies focused solely on boosting mean income do. In other words, according to the results presented here, economic growth policies that promote both an increase in income and a reduction in inequality (for example, policies targeting the poorest segments of the Brazilian population, such as the Bolsa Familia programme) tend to reduce poverty more than economic growth policies whose sole aim is to raise mean income levels.

\section{Bibliography}

Adams, R.H. (2004), "Economic growth, inequality and poverty: estimating the growth elasticity of poverty", World Development, vol. 32, No. 12, Amsterdam, Elsevier.

Ahn, S.C. and P. Schmidt (1995), "Efficient estimation of models for dynamic panel data", Journal of Econometrics, vol. 68, No. 1, Amsterdam, Elsevier.

Araújo, J.A., F.J.S. Tabosa and A.S. Khan (2012), "Elasticidade renda e elasticidade desigualdade da pobreza no Nordeste brasileiro", Revista de Política Agrícola, No. 1.

Arellano, M. and S. Bond (1991), "Some tests of specification for panel data: Monte Carlo evidence and an application to employment equations", The Review of Economic Studies, vol. 58, No. 2, Oxford University Press.

Arellano, M. and O. Bover (1995), "Another look at the instrumental-variable estimation of error components model", Journal of Econometrics, vol. 68, No. 1, Amsterdam, Elsevier.

Banerjee, A. and E. Duflo (2003), "Inequality and growth: what can the data say?", Journal of Economic Growth, vol. 8, No. 3, Springer.

Barreto, F. (2005), "Crescimento econômico, pobreza e desigualdade: o que sabemos sobre eles?", Série Ensaios Sobre Pobreza, No. 1, Fortaleza.

Barreto, F., J.M. França and V.H. de Oliveira (2008), "O que mais importa no combate à pobreza, crescimento econômico ou redução da desigualdade: evidências para as regiões brasileiras", Série Ensaios Sobre Pobreza, No. 16, Fortaleza.

Barreto, F., P.J. Melo Neto and E. Tebaldi (2001), "Desigualdade de renda e crescimento econômico no nordeste brasileiro", Revista Econômica do Nordeste, vol. 32, No. 9.

Barro, R. (2000), "Inequality and growth in a panel of countries", Journal of Economic Growth, vol. 5, No. 1, Springer.

Barros, P.R. and others (2007), "Determinantes imediatos da queda da desigualdade de renda brasileira", Texto para Discussão, No. 1253, Rio de Janeiro, Institute of Applied Economic Research.

Blundell, R. and S. Bond (1998), "Initial conditions and moment restrictions in dynamic panel data models", Journal of Econometrics, vol. 87, No. 1, Amsterdam, Elsevier.

Bourguignon, F. (2002), "The growth elasticity of poverty reduction: explaining heterogeneity across countries and time periods", Inequality and Growth: Theory and Policy Implications, T. Eicher and S. Turnovsky, Cambridge, Massachusetts, The MIT Press.

Castelar, P. (2007), "Crescimento econômico e desigualdade de renda no Brasil: uma análise de painel dinâmico para o período 1985-2002", Fortaleza, Federal University of Ceara. 
Chen, S. and Y. Wang (2001), "China's growth and poverty reduction: recent trends between 1990 and 1999", Policy Research Working Paper, No. 2651, Washington, D.C., World Bank.

De Lima, F.S., F. Barreto and E. Marinho (2003), "Impacto do crescimento econômico e da concentração de renda sobre o nível de pobreza dos estados brasileiros", Anais do VII Encontro Regional de Economia, Fortaleza.

Deineger, K. and L. Squire (1998), "New ways of looking at old issues: inequality and growth", Journal of Economic Development, vol. 57, No. 2, Amsterdam, Elsevier.

Diniz, M.B. (2005), "Contribuições ao estudo da desigualdade de renda entre os estados brasileiros", thesis, Fortaleza, Federal University of Ceara.

Easterly, W. (2000), "The Effect of IMF and World Bank Programs on Poverty", Washington, D.C., World Bank, unpublished.

Ferreira, F. (1999), A Brief Overview of Theories of Growth and Distribution, Washington, D.C., World Bank.

Ferreira, F., P. Lanjouw and M.C. Neri (2003), "A robust poverty profile for Brazil using multiple data sources", Revista Brasileira de Economia, vol. 57, No. 1.

Ferreira, R.T. and M.S. Cruz (2010), "Efeitos da educação, da renda do trabalho, das transferências e das condições iniciais na evolução da desigualdade de renda nos municípios brasileiros no período de 1991 a 2000", Pesquisa e Planejamento Econômico, vol. 40, No. 1.

Fields, G. and G. Jakubson (1994), "The Inequality-Development Relationship in Developing Countries", unpublished.

Figueiredo, E. and M.P. Laurini (2015), "Poverty elasticity: a note on a new empirical approach", Review of Income and Wealth, vol. 62, No. 2, Wiley.

Fishlow, A. (1972), "Brazilian size distribution of income", American Economic Review, vol. 62, No. 2, Nashville, Tennessee, American Economic Association.

Forbes, K.A. (2000), "A reassessment of the relationship between inequality and growth", American Economic Review, vol. 90, No. 4, Nashville, Tennessee, American Economic Association.

Foster, J., J. Greer and E. Thorbecke (1984), "A class of decomposable poverty measures", Econometrica, vol. 52, No. 3, New York, The Econometric Society.

Fosu, A.K. (2010), "Growth, inequality, and poverty reduction in developing countries: recent global evidence", Working Paper, No. 2011/01, World Institute for Development Economics Research (UNU-WIDER).

França, J.M.S. (2010), "Crescimento pró-pobre no Brasil: impactos regionais", thesis, Rio de Janeiro.

Hoffmann, R. (2005), "Elasticidade da pobreza em relação à renda média e à desigualdade no Brasil e nas unidades da federação", Economia, vol. 6, No. 2.

- (1998), Distribuição de renda: medidas de desigualdade de renda e pobreza, São Paulo, Editora da Universidade de São Paulo (EDUSP).

IPEA (Institute of Applied Economic Research), "IPEADATA" [online] www.ipeadata.gov.br.

$\mathrm{Li}, \mathrm{H}$. and H. Zou (1998), "Income inequality is not harmful for growth: theory and evidence", Review of Development Economics, vol. 2, No. 3, Wiley Blackwell.

Litchfield, J.A. (1999), "Inequality: methods and tools", unpublished.

López, J.H. and L. Seven (2004), "The mechanics of growth-poverty-inequality relationship", unpublished.

Kakwani, K., S. Khandker and H. Son (2004), "Pro-poor growth: concepts and measurement with country case studies", Working Paper, No. 1, Brasilia, International Poverty Centre.

Kakwani, N., M.C. Neri and H. Son (2010), "Linkages between pro-poor growth, social programs and labor market: the recent Brazilian experience", World Development, vol. 38, No. 6, Amsterdam, Elsevier.

Kakwani, K. and E. Pernia (2000), "What is pro-poor growth?", Asian Development Review, vol. 18, No. 1, Asian Development Bank.

Kraay, A. (2004), "When is growth pro-poor? Cross-country evidence", Policy Research Working Paper Series, No. 3225, Washington, D.C., World Bank.

Kuznets, S. (1955), "Economic growth and income inequality", American Economic Review, vol. 45, Nashville, Tennessee, American Economic Association.

Manso, C.A., F. Barreto and E. Tebaldi (2006), "O desequilíbrio regional brasileiro: novas perspectivas a partir das fontes de crescimento pró-pobre”, Série Ensaios sobre Pobreza, No. 6, Fortaleza.

Marinho, E. and F. Soares (2003), "Impacto do crescimento econômico e da concentração de renda sobre a redução da pobreza nos estados brasileiros", Anais do Encontro Nacional da Economia, Porto Seguro.

Marinho, E. and J. Araújo (2010), "Pobreza e o sistema de seguridade social rural no Brasil", Revista Brasileira de Economia, vol. 64, No. 2. 
Marinho, E., F. Linhares and G. Campelo (2011), "Os programas de transferência de renda do governo impactam a pobreza no Brasil?", Revista Brasileira de Economia, vol. 65, No. 3.

Menezes, T.A. and R.F. Pinto (2005), "É preciso esperar o bolo crescer, para depois repartir?", Anais do VIII Encontro Regional de Economia, Fortaleza.

Netto, Júnior, J.L. da S. and E. Figueiredo (2014), "Crescimento pró-pobre no Brasil e nas regiões no período de 1987-2007: uma abordagem não paramétrica”, Planejamento e Políticas Públicas, No. 42.

Ravallion, M. (1997), "Can high-inequality developing countries escape absolute poverty?", Economic Letters, vol. 56, No. 1, Amsterdam, Elsevier.

- (2004), "Pro-poor growth: a primer", Policy Research Working Papers, No. 3242, Washington, D.C., World Bank.

Ravallion, M. and S. Chen (2003), "Measuring pro-poor growth", Policy Research Working Paper, No. 2666, Washington, D.C., World Bank.

(1997), "What can new survey data tell us about recent changes in distribution and poverty?", World Bank Economic Review, vol. 11, No. 2, Washington, D.C., World Bank.

Ribas, R.P., A.F. Machado and A.B. Golgher (2006), "Fluctuations and persistence in poverty: a transientchronic decomposition model for pseudo-panel data", Texto para Discussão, No. 289, Federal University of Minas Gerais.

Rocha, S. (2006), Pobreza no Brasil. Afinal de que se trata?, Rio de Janeiro, FGV Editora.

Rodrik, D. (2000), "Growth versus poverty reduction: a hollow debate", Finance \& Development, vol. 37, No. 4, Washington, D.C., International Monetary Fund.

Stewart, F. (2000), Distribuição de renda e desenvolvimento, Brasilia, NEAD.

Windmeijer, F. (2005), "A finite sample correction for the variance of linear efficient two-step GMM estimators", Journal of Econometrics, vol. 126, No. 1, Amsterdam, Elsevier. 